\title{
УДК 662.931
}

\section{ЦЕЛЕСООБРАЗНОСТЬ ИСПОЛЬЗОВАНИЯ ТВЕРДОТОПЛИВНЫХ КОТЛОВ НА ПРЕДПРИЯТИЯХ ЖЕЛЕЗНОДОРОЖНОГО ТРАНСПОРТА}

\author{
А.П. Фалендыш, Л.А. Пархоменко, О.В. Клецкая, П.В. Рукавишников \\ ДОЦЛЬНІСТЬ ВИКОРИСТАННЯ ТВЕРДОПАЛИВНИХ КОТЛІВ НА \\ ПІДПРИЕМСТВАХ ЗАЛІЗНИЧНОГО ТРАНСПОРТУ.
}

\author{
А.П. Фалендиш, Л.О. Пархоменко, О.В. Клецька, П.В. Рукавішников
}

THE FEASIBILITY OF USING SOLID FUEL BOILERS FOR RAILWAY ENTERPRISES

\author{
A. Falendysh, L. Parkhomenko, O. Kletska, P. Rukavishnikov
}

Сделан анализ структуры расходов условного топлива и прогнозирование потребления различных видов котельно-печного топлива. Для целесообразности использования других видов топлива в котельных был сделан прогноз стоимости энергоресурсов на производство тепловой энергии. Выполнена классификация отопительных котлов при использовании разного вида топлива. Рассмотрены основные технические характеристики разных типов котлов, их преимущества и недостатки. Определена целесообразность использования твердотопливных котлов на предприятиях железнодорожного транспорта.

Ключевые слова: Отопительный котел, котельно-печное топливо, тепловая энергия, прогнозирование, коэффициент полезного действия.

Зроблений аналіз структури витрат умовного палива та прогнозування споживання різних видів котельно-пічного палива. Для дочільності використання іниих видів палива в котельнях був зроблений прогноз вартості енергоресурсів на виробництво теплової енергії. Виконана класифікація опалювальних котлів при використанні різного виду палива. Розглянуто основні технічні характеристики різних типів котлів, їх переваги та недоліки. Визначено доцільність використання твердопаливних котлів на підприємствах залізничного транспорту.

Ключові слова: Опалювальний котел, котельно-пічне паливо, теплова енергія, прогнозування, коефіиієнт корисної дї.

The analysis of the costs of fuel oil, on the basis of Ukrzaliznytsia, which showed a tendency to reduce the consumption of coal, oil and natural gas in recent years. The analysis of the cost structure of conventional fuel and forecasting of consumption of various types of fuel oil. For the feasibility of using other types of fuel in the boiler was made the forecast cost of energy for heat generation. Made classification of boilers using different types of fuel. The main technical characteristics of the different types of boilers and their advantages and disadvantages. Analysis of the structure building area Ukrzaliznytsia enterprises, namely enterprises locomotive economy, carload economy showed prospects of solid fuel boilers: brigadier house locomotive crews; 
checkpoints road crossings, stations, remote areas of railway transport determine the feasibility of using solid fuel boilers at the enterprises of railway transport. efficiency.

Keywords: Boiler, boiler and furnace fuels, thermal energy, forecasting, coefficient of

Введение. В настоящее время на предприятиях железнодорожного транспорта для получения тепловой энергии используются, в основном, котельные большой мощности, работающие на газу. Они используются не только для получения тепловой энергии для нужд предприятия, но и для отопления прилегающих поселков и городов.

В сложившейся ситуации, при резком уменьшении объемов перевозок и ремонтных работ, данные котельные используются не на полную мощность, что приводит к увеличению себестоимости тепловой энергии. Если учесть еще дефицит и дороговизну газа, то целесообразность использования газовых котелень большой мощности вызывает сомнение. Поэтому обоснование использования твердотопливных котлов длительного горения небольшой мощности в настоящее время является актуальным.

\section{Цель.}

целесообразности отопительных твердотопливных котлов длительного горения малой мощности на предприятия железнодорожного транспорта.

Основная часть. Анализ расходов на нужды котелень, на основе данных Укрзализныци за 1997-2014 гг. (рис. 1), показывает, что потребление угля, мазута и природного газа за последнее время имеет тенденцию до уменьшения потребления. Но события, происходящие в нашей стране с 2014 года показывают, что полученные регрессии для прогнозирования в настоящее время использовать нельзя. Потребление газа резко уменьшается и прогнозируемое значение не соответствует полученной регрессионной зависимости. Поэтому для анализа и прогнозирования расхода котельно-топочного топлива за базовый брались данные 2013 года. Прогнозирование выполнялось экспертным методом, с корректировкой статистических данных Укрзализныци.

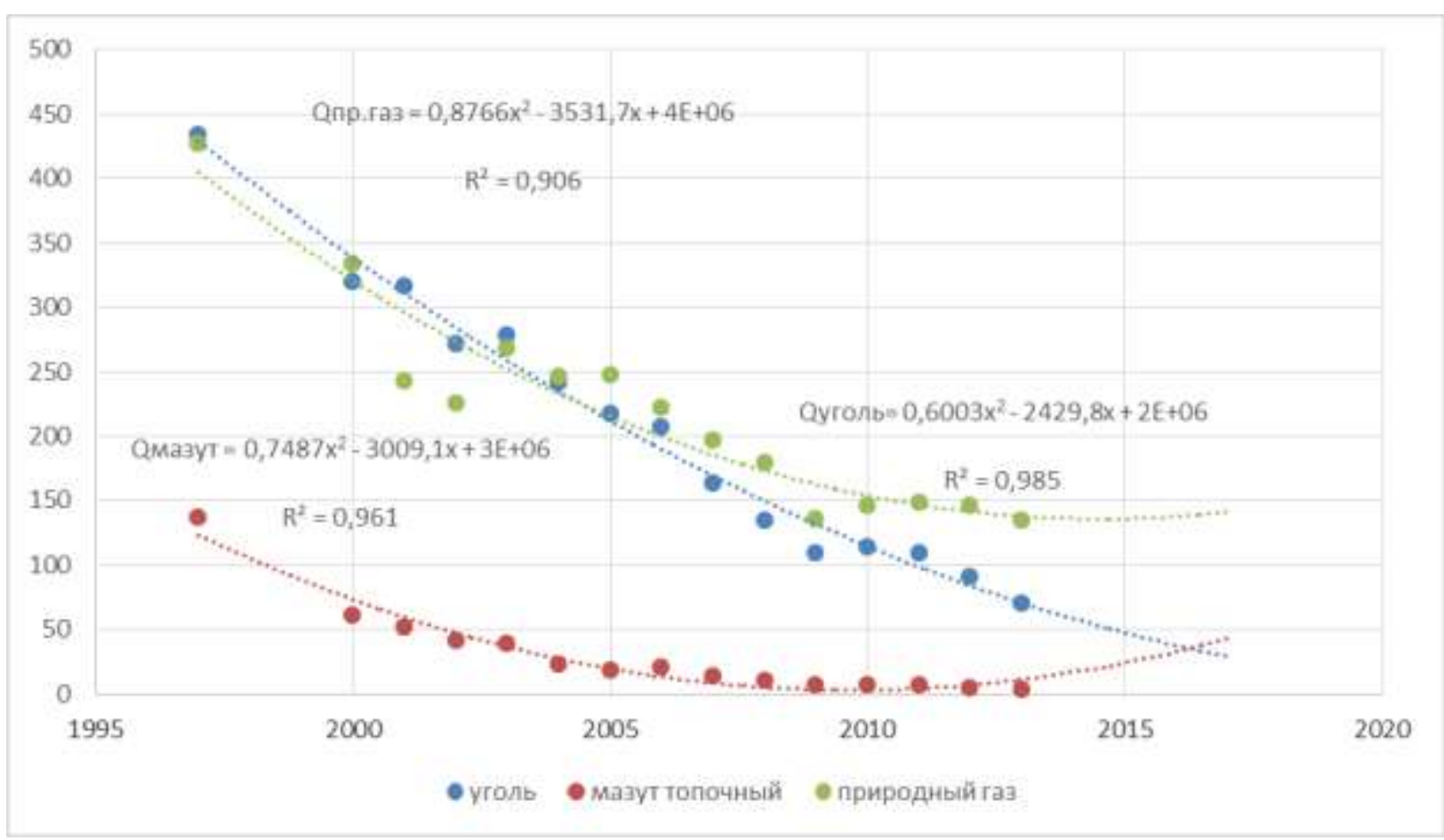

Рис.1 Прогнозирование потребления различных видов котельно-печного топлива. 
Вначале был сделан анализ пассажирских вагонов - 27,1 т.у.т., на структуры расходов условного топлива 2013 жилищно-коммунальное потребление - 26,6 года (рис. 2), который показал, что расход т.у.т., на нагрев металла и литье - 1,9 т.у.т. и условного топлива на производство тепловой на другие производственные потребности энергии составляет 145,4 т.у.т., на отопление 28,1 т.у.т.

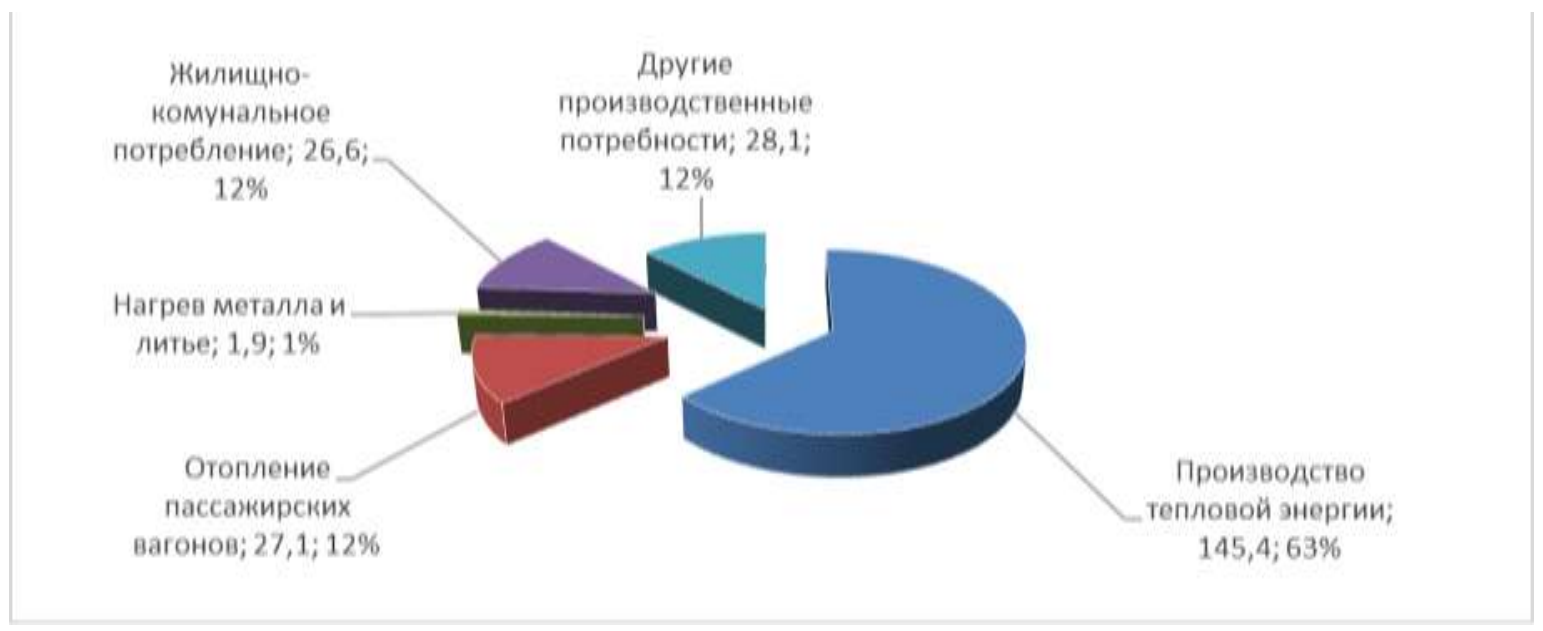

Рис. 2. Структура расходов условного котельно-топочного топлива за 2013 г.

Так как идет модернизация и обновление пассажирских вагонов, в которых применяется электрическое отопление, то прогнозное потребление котельно-топочного топлива на отопление пассажирских вагонов составляет 7,1 т.у.т. С уменьшением объема робот прогнозируется уменьшение потребления топлива на производство тепловой энергии до 124 т.у.т., на нагрев металла и литье до 1,5 т.у.т., на жилищно-коммунальное потребление до 26,5 т.у.т. и на другие производственные потребности потребление тонн условного топлива составит 11 т.у.т. (рис. 3).
Анализ структуры площадей зданий предприятий Укрзализныци, а именно предприятий локомотивного хозяйства, вагонного хозяйства, станций и узлов и др., показал, что около 30 \% помещений имеют площадь менее $800 \mathrm{~m}^{2}$. Поэтому эти здания можно отапливать твердотопливными котлами небольшой мощности, и расходы топлива на жилищно-коммунальное потребление были разделены на расходы потребления топлива котлами мощностью более 100 кВт и котлами мощностью менее 100 кВт.

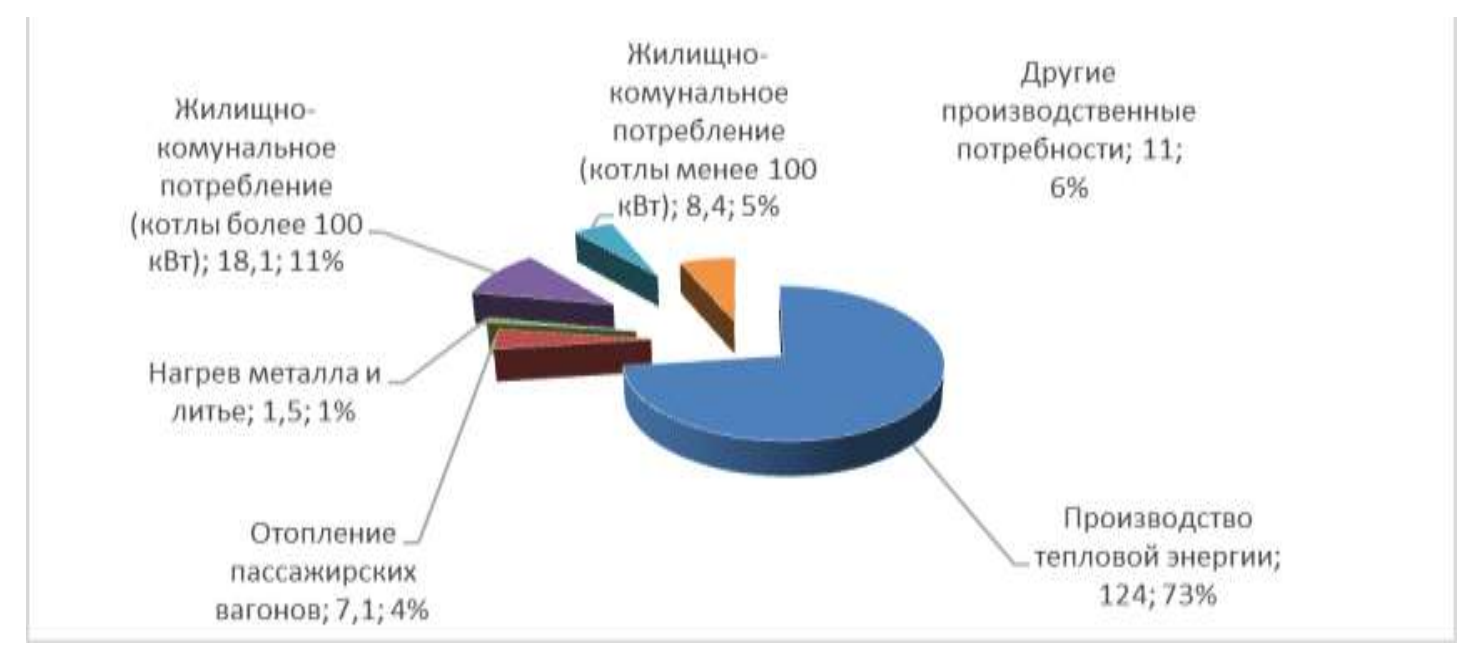

Рис. 3. Прогнозная структура расходов условного котельно-топочного топлива на 2015 г. 
нее видно, что стоимость 1 Гкал на

использования других видов топлива в природном газе увеличится более чем в 2,5 котельных был сделан прогноз стоимости энергоресурсов на производство тепловой энергии. За базовый были взяты данные 2013 года (рис. 4). На основании прогнозных данных стоимости топлива на 2015 г. (рис. 5) была построена диаграмма стоимости 1 Гкал тепловой энергии от котельных, использующих различные виды топлива. Из раза и будет составлять около 1500 грн., в тоже время стоимость 1 Гкал на дровах будет почти на 1300 грн. меньше относительно природного газа. В 2013 году разница составляла около 400 грн., что еще раз говорит о целесообразности внедрения современных твердотопливных котлов.

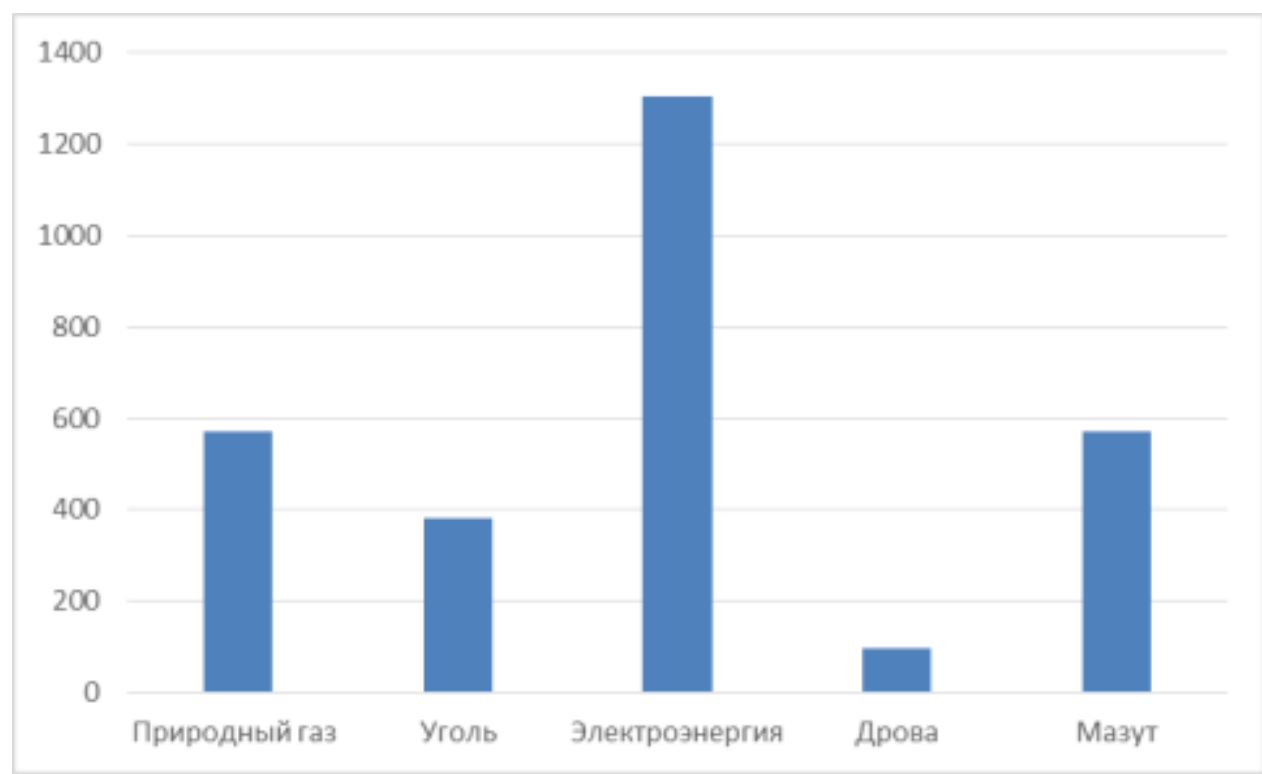

Рис. 4. Диаграмма стоимости 1 Гкал тепловой энергии от котельных на различных видах топлива за 2013 г.

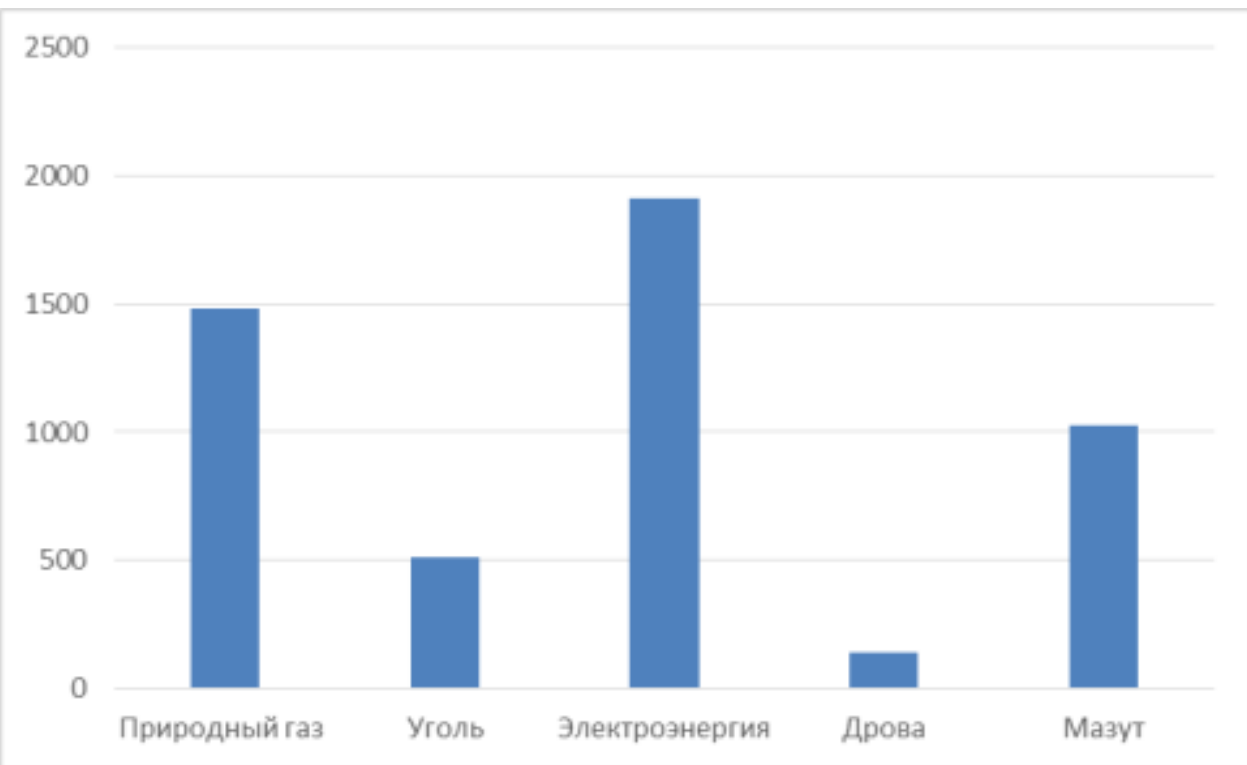

Рис. 5. Диаграмма стоимости 1 Гкал тепловой энергии от котельных на различных видах топлива в 2015 г.

На сегодняшний день на рынке и импортного производства, которые отопительных систем присутствует отличаются размерами, формами, типом множество котлов отопления отечественного топлива, эксплуатационными 
характеристиками.

Была

сделана

виду потребляемого топлива (рис. 6).

классификация отопительных котлов по

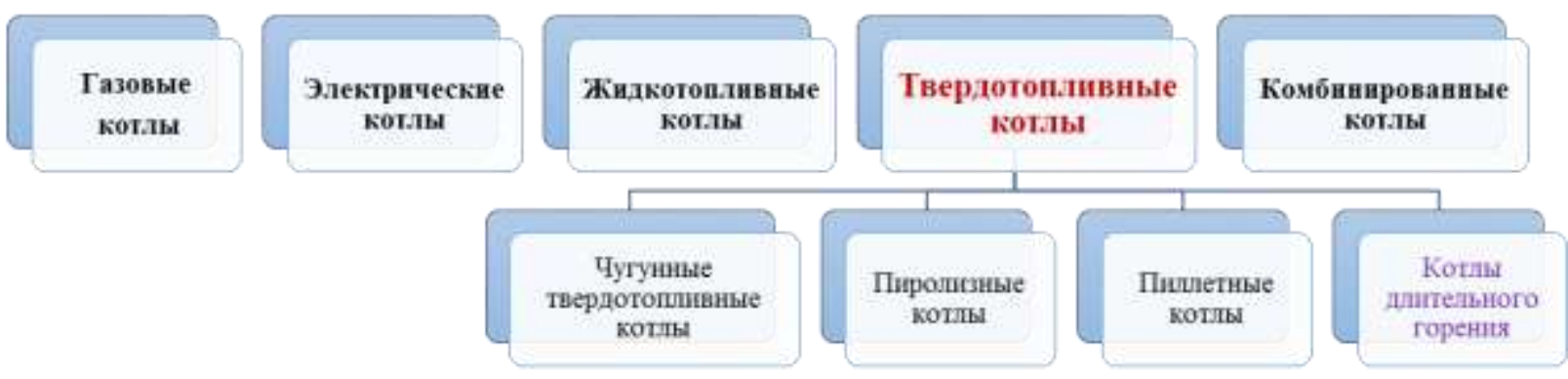

Рис. 6. Классификация отопительных котлов по виду потребляемого топлива.

котлов.

Рассмотрим кратко данные виды

Газовые котлы отопления - самые распространённые и популярные. Просты в эксплуатации, долговечны, эффективны для обогрева больших помещений, при высоком КПД у газовых котлов низкая стоимость топлива (газа). Это наиболее распространенный вид котлов. Недостатки газовых котлов: они более опасны в эксплуатации в сравнении с другими видами, их обязательно оборудуют автоматикой, и для их установки обязательно утверждение проектной документации к котлу соответствующими службами $[5,7,8]$.

Электрические котлы просты в монтаже и эксплуатации, обладают высоким КПД, компактны, бесшумны, экологичны (без вредных выбросов), и имеют высокую степень безопасности. Их недостатки - они имеют большое энергопотребление, требуют отдельную проводку (при мощности котла более 6 КВТ для установки котла нужна трехфазная сеть электропроводки с напряжением 380 В) и не работают при перебоях электропитания $[6,7,8]$.

Жидкотопливные

котлы предназначены для автономных систем отопления. Они работают на дизельном топливе (солярке), это наиболее дорогой вид отопления. Его преимущества - высокий КПД (до 94\%), автоматизация процесса отопления, бесшумность работы $[9,10]$.

$$
\text { Главные }
$$

преимущества комбинированных котлов (двух-, трехтопливных) - работа на разных видах топлива. К их недостаткам относят высокую стоимость, крупные габариты, необходимость подвода электричества. КПД комбинированных котлов ниже на 10-20\% в сравнении с другими моделями [11].

Котлы на твердом топливе имеют ряд преимуществ, по сравнению с остальными видами котлов. К ним относятся: доступность, автономность и дешевизна топлива. Благодаря именно этим достоинствам твердотопливные котлы пользуются популярностью в районах, где имеются трудности с поставками электричества или газа. Ассортимент твердотопливных котлов очень высок, а топливо для них (например, каменный уголь) при относительно невысокой стоимости дает огромный тепловой эффект.

Основные технические характеристики разных типов котлов, их преимущества и недостатки представлены в таблице 1. 


\begin{tabular}{|c|c|c|c|c|c|}
\hline $\begin{array}{c}\text { Показател } \\
\text { и }\end{array}$ & $\begin{array}{c}\text { Газовые } \\
\text { котлы }\end{array}$ & $\begin{array}{c}\text { Электрические } \\
\text { котлы }\end{array}$ & $\begin{array}{l}\text { Жидкотоп- } \\
\text { ливные } \\
\text { котлы }\end{array}$ & $\begin{array}{c}\text { Комбиниро- } \\
\text { ванные } \\
\text { котлы }\end{array}$ & $\begin{array}{c}\text { Твердотоплив } \\
\text {-ные } \\
\text { котлы }\end{array}$ \\
\hline 1 & 2 & 3 & 4 & 5 & 6 \\
\hline $\begin{array}{c}\text { Модель, } \\
\text { произво- } \\
\text { дитель }\end{array}$ & $\begin{array}{c}\text { МАЯК-10Р, } \\
\text { Маяк }\end{array}$ & $\begin{array}{l}\text { Dakon Daline } \\
\text { PTE 10, Dakon }\end{array}$ & $\begin{array}{l}\text { Гелиос-10, } \\
\text { Автодеталь }\end{array}$ & $\begin{array}{l}\text { Uragan-10, } \\
\text { Термокрафт }\end{array}$ & $\begin{array}{c}\text { Донтерм } \\
\text { КОТ- 10Т, } \\
\text { Донтерм }\end{array}$ \\
\hline Топливо & $\begin{array}{c}\text { Природный } \\
\text { газ }\end{array}$ & $\begin{array}{c}\text { Электроэнерги } \\
\text { я }\end{array}$ & $\begin{array}{l}\text { Отработка } \\
\text { масла, } \\
\text { мазут }\end{array}$ & $\begin{array}{c}\text { Твердое } \\
\text { топливо, } \\
\text { электроэнер } \\
\text { гия }\end{array}$ & $\begin{array}{c}\text { Дрова, щепа, } \\
\text { опилки, } \\
\text { пеллеты, } \\
\text { брикеты, } \\
\text { кора, } \\
\text { каменный } \\
\text { уголь, кокс, } \\
\text { торф, } \\
\text { горючие } \\
\text { сланцы }\end{array}$ \\
\hline КПД, \% & 90 & 99 & $88-92$ & 85 & 90 \\
\hline $\begin{array}{c}\text { Мощност } \\
\text { ь, кВт }\end{array}$ & 10 & 10 & 10 & 10 & 10 \\
\hline $\begin{array}{c}\text { Температ } \\
\text { у-ра на } \\
\text { выходе, } \\
{ }^{\circ} \mathrm{C}\end{array}$ & 90 & 90 & 80 & 95 & 95 \\
\hline $\begin{array}{c}\text { Расход } \\
\text { топлива, }\end{array}$ & $1,12 \mathrm{M}^{3} / \mathrm{\Psi}$ & 10,1 кВт/ч & 0,86 & $\begin{array}{c}1,2 \text { кг/ч, } \\
10,3 \text { кВт/ч }\end{array}$ & 1.2 кг/час \\
\hline $\begin{array}{c}\text { Отапли- } \\
\text { ваемая } \\
\text { площадь, } \\
\text { м² }^{2}\end{array}$ & 100 & 120 & 120 & 100 & 100 \\
\hline $\begin{array}{c}\text { Преиму- } \\
\text { щества }\end{array}$ & $\begin{array}{c}\text { Экономично } \\
\text { сть. } \\
\text { Простота в } \\
\text { использован } \\
\text { ии. } \\
\text { Высокий } \\
\text { КПД при } \\
\text { малом } \\
\text { расходе } \\
\text { газа. }\end{array}$ & $\begin{array}{c}\text { Безопасность. } \\
\text { Легкость. } \\
\text { Простота в } \\
\text { использовании. } \\
\text { Бесшумность. } \\
\text { Отсутствие } \\
\text { копоти. }\end{array}$ & $\begin{array}{c}\text { Высокий } \\
\text { КПД. } \\
\text { Способност } \\
\text { ь } \\
\text { отапливать } \\
\text { большие } \\
\text { помещения. }\end{array}$ & $\begin{array}{c}\text { Возможност } \\
\text { ь } \\
\text { использован } \\
\text { ия разных } \\
\text { видов } \\
\text { топлива. }\end{array}$ & $\begin{array}{c}\text { Наиболее } \\
\text { экологически } \\
\text { чистые. } \\
\text { Недорогое } \\
\text { топливо. } \\
\text { Автономност } \\
\text { ь. }\end{array}$ \\
\hline $\begin{array}{c}\text { Недостат } \\
\text { ки }\end{array}$ & $\begin{array}{c}\text { Необходимо } \\
\text { сть } \\
\text { автоматики, } \\
\text { проектной } \\
\text { документац } \\
\text { ии и газовой } \\
\text { магистрали. }\end{array}$ & $\begin{array}{c}\text { Большое } \\
\text { энергопотребле } \\
\text {-ние. } \\
\text { Необходимость } \\
\text { дополнительно } \\
\text { й проводки. } \\
\text { Зависимость от } \\
\text { электропитани } \\
\text { я. }\end{array}$ & $\begin{array}{c}\text { Необходи- } \\
\text { мость } \\
\text { большой } \\
\text { емкости } \\
\text { для } \\
\text { топлива и } \\
\text { отдельного } \\
\text { помещения. } \\
\text { Копоть. }\end{array}$ & $\begin{array}{c}\text { Сложность и } \\
\text { дороговизна } \\
\text { в } \\
\text { эксплуатаци } \\
\text { и и ремонте. }\end{array}$ & $\begin{array}{c}\text { Необходимос } \\
\text { ть помещения } \\
\text { для хранения } \\
\text { топлива. }\end{array}$ \\
\hline
\end{tabular}


Рассматривая

B

работе

твердотопливные котлы, были выделены следующие виды. Первый и самый распространенный вид - чугунные твердотопливные котлы предназначенные для сжигания угля и дров. Да эти котлы демонстрируют достаточно удобный цикл работы, энергонезависимы. Но основным видом топлива для них всё же является уголь. Дрова в них горят достаточно быстро - не более 3-4 часов, что в свою очередь вызывает некоторый дискомфорт. Классический пример такого котла - это отечественный КЧМ, а зарубежный - серия Solida, от производителя Sime [12, 13].

Второй вид - пиролизные котлы отличительная особенность - наличие двух камер сгорания: в первой происходит первичное горение (в этой камере искусственно создается дефицит кислорода, что приводит к процессу пиролиза и генерации синтез газа), во второй камере происходит догорание синтез газа. Основным видом топлива для данного вида котлов выступает древесина, желательно твердых пород. Время горения такого котла на одной закладке - от 6 до 10 часов. КПд при этом достигает уровня не менее 90\%. Пример такого котла - Чешский Dakon серии KP Pyro [14].

Третий вид - пиллетные котлы. В этих котлах в качестве топлива используется прессованная и гранулированная древесина пиллеты. Котел самостоятельно с помощью шнека подсыпает в зону горения необходимое количество топлива. Розжиг этого вида котлов также автоматический. Время горения котла зависит исключительно от емкости бункера. В отдельных случаях такие котлы комплектуются пневмоподачей топлива из хранилища. Для таких котлов топливо завозится один раз в сезон, далее весь процесс автоматизирован. Единственным недостатком данного вида котлов - это невозможность сжигать что либо кроме древесных гранул [15].

Следующий вид - это котлы длительного горения. В данном подвиде котлов используются преимущественно дрова и опилки - но возможны варианты с углем и смесями угля, торфа и дров. Время горения данного вида котла составляет от 12 часов до двух суток и это на дереве. Недостатки этих котлов - это необходимость помещения для хранения твердого топлива и ручная загрузка топлива [16].

Котлы длительного горения не нуждаются в накопителях тепла - время горения позволяет обходится без них.

Твердотопливные

котлы длительного горения целесообразно использовать для отопления удаленных помещений небольшой площади локомотивных и вагонных депо; бригадных домов и домов отдыха локомотивных бригад; пункты контроля железнодорожных переездов автотранспортом; железнодорожные станции и узлы.

\section{Выводы.}

1. Сделанный анализ расходов на нужды котелень по Укрзализныци за 1997 2014 гг. показал целесообразность использование твердого топлива, преимущественно дрова.

2. Перспективы использования твердотопливных котлов: бригадные дома локомотивных бригад; пункты контроля железнодорожных переездов автотранспортом, станции, удаленные помещения предприятий железнодорожного транспорта.

3. На основании существующей литературы экспертным методом определены основные характеристики котлов. К ним отнесены: вид топлива; номинальная мощность; основные функции котла; степень автоматизации котельного оборудования; вес и габариты котла.

4. По виду потребляемого топлива сделана классификация отопительных котлов: газовые, электрические, комбинированные и твердотопливные котлы. Были наведены их краткие характеристики.

5. Для улучшения технических характеристик необходимо в будущем усовершенствовать конструкцию котла, параметры топки, рассчитать оптимальные размеры котла. 


\section{Список використаних джерел}

1. http://bookz.ru/authors/sbornik-statei/bitovie-_669/1-bitovie-_669.html.

2. В.А. Григорьев Промышленная теплоэнергетика и теплотехника [Текст] / В.А. Григорьев, В.М. Зорин - М.: Энергоатомиздат, 1983. - 552 с.

3. В.А. Маляренко Енергозбереження в житлово-комунальному господарстві. Частина І. [Текст] / В.А. Маляренко, Л.М. Шутенко -Энергосбережение. Энергетика. Энергоаудит. 2005 №7 - 2-9 с.

4. В.Н. Пуль Автономное теплоснабжение [Текст] / В.Н. Пуль - Энергосбережение. Энергетика. Энергоаудит. 2006 №1 - 37-38 с.

5. www.otopimdom.ru/index.php?id=35.

6. И. С. Жигулина Особенности применения электрического отопления [Текст] / И. С. Жигулина, А. И. Алифанова - Современные наукоемкие технологии. Журнал № 8-1 / 2013 $-41-42 \mathrm{c}$.

7. С.Г. Каспаров Реконструкция системы отопления нефтебазы «Харьковская» [Текст] / С.Г. Каспаров, Н.В. Кирилин -Энергосбережение. Энергетика. Энергоаудит. 2007 №3 - 101-111 c.

8. А. Н. Сканави Отопление. [Текст] / А. Н. Сканави Учебник для вузов. - М.: АСВ, 2008. C. 576. ISBN 978-5-93093-161-7.

9. ГОСТ 30735-2001. Котлы отопительные водогрейные теплопроизводительностью от 0,1 до 4,0 МВт, ОКС 27.060.30, 97.100, ОКП 49 3120, Дата введения 2003-01-01.

10. http://www.kotloved.ru/santechnik2002_2.html.

11. http://stroy-aqua.com/vodosnab_otopl/kotel/kombinirovannye-kotly-otopleniya.html.

12. http://sime.com.ua/ru/napolnye tverdotoplivnye kotly/kotel-sime-solida.html.

13. http://www.termoles.ru/kotly-kchm.html?showall=\&start=2.

14. http://www.dakon.in.ua/produktsiya/tverdotoplivnye-kotly/piroliznye-stalnye-kp-pyro.

15. http://b2b-ua.com/invent-pelletnie kotli.html.

16. http://pelletshome.com.ua/ru/14-kotli-dlitelnogo-goreniya.

17. http://www.uipv.org/ua/bases2.html/

Фалендыш Анатолий Петрович, д.т.н., заведующий кафедры теплотехники и тепловых двигателей Украинского государственного университета железнодорожного транспорта, г. Харьков, Украина, Тел. (057)730-10-77. E-mail: fap_hiit@ @ambler.ru.

Пархоменко Лариса Алексеевна, к.т.н., старший преподаватель кафедры теплотехники и тепловых двигателей Украинского государственного университета железнодорожного транспорта, г. Харьков, Украина, Тел. (057)-730-10-78.

Клецкая Ольга Витальевна, аспирант кафедры теплотехники и тепловых двигателей Украинского государственного университета железнодорожного транспорта, г. Харьков, Украина, Тел. (057)-730-10-78. Еmail: gurao@yandex.ru.

Рукавишников Павел Владимирович, старший преподаватель кафедры теплотехники и тепловых двигателей Украинского государственного университета железнодорожного транспорта, г. Харьков, Украина, Тел. (057)-730-10-78. E-mail: pasha0776@mail.ru.

Falendysh Anatoliy d-r science, professor department of operation and maintenance of rolling stock Ukraine State University of Railway Transport. Tel.: (057) 730-21-25. E-mail: fap_hiit@ rambler.ru.

Parkhomenko Larisa, Senior Lecturer, Department of Thermal Engineering and Heat Engines Ukrainian State University of railway competition, Kharkov, Ukraine, Tel. (057) -730-10-78.

Kletska Olga aspirant the Department of Thermal Engineering and Heat Engines Ukraine State University of Railway Transport Tel.: (057) 730-10-78. E-mail: gurao@yandex.ru.

Rukavishnikov Pavel, Senior Lecturer, Department of Thermal Engineering and Heat Engines Ukrainian State University of railway competition, Kharkov, Ukraine, Tel. (057) -730-10-78. E-mail: pasha0776@mail.ru.

Стаття поступила 21.04.2015 